\title{
Spawanie laserowe żeber usztywniających kadłuba nośnego silnika lotniczego
}

\section{Laser Welding of Stiffening Ribs to the Casing of a Jet Engine}

\section{Streszczenie}

W artykule przedstawiono wyniki badań procesu spawania laserowego bez materiału dodatkowego złączy teowych ze spoiną czołową stosowanych w konstrukcji paneli kadłuba nośnego ze stali AISI 17-4PH (X5CrNiCuNb16-4) o grubości 1,0 $\mathrm{mm}$ i 1,5 mm. Przeprowadzono dobór parametrów spawania jednostronnego i dwustronnego, zbadano wpływ ustawienia wiązki laserowej względem styku łączonych elementów na jakość złącza wg PN-EN ISO 13919-1. Wykonano fragment rzeczywistego panelu kadłuba nośnego. Określono ograniczenia stosowania technologii spawania laserowego związane z przygotowaniem elementów do spawania.

Słowa kluczowe: spawanie laserowe bez materiału dodatkowego złączy teowych ze spoiną czołową; stal nierdzewna; kadłub nośny silnika lotniczego

\begin{abstract}
The study addresses the results concerning the autogenous laser welding of T-joint with a butt weld used in the structure of casing panels. The joints were made of 1 and 1,5 mm thick AISI 17-4PH (X5CrNiCuNb16-4) steel. Exemplary welding parameters were determined. The influence of the beam setting in relation to the interface of sheets over joint quality according to PN-EN ISO 13919-1 was investigated. An Actual Test Elements of the Casing with the Stiffening Ribs was welded. Limitations on the use of laser welding technology related to the preparation of welding elements have been specified.
\end{abstract}

Keywords: autogenous laser welding of T-joint with a butt weld; stainless steel; aircraft engine casing

\section{Wstęp}

Procesy spawania charakteryzują się tym, że w obszarze spawania do łączonych elementów wprowadzane są znaczne ilości ciepła. Dzięki temu możliwe jest stopienie brzegów materiałów łączonych, ewentualnie materiału dodatkowego, które krzepnąc tworzą spoinę. Każde wprowadzenie ciepła do materiałów łączonych, lokalne nagrzanie materiałów powyżej ich temperatury topienia, powoduje powstawanie naprężeń i odkształceń w złączach spawanych. W przypadku stali nierdzewnych odkształcenia te są znacznie większe niż w przypadku spawania stali niestopowych, ze względu na różnice we właściwościach fizyko-chemicznych (wysoki współczynnik rozszerzalności cieplnej, niski współczynnik przewodnictwa cieplnego) [1,2]. Stanowi to pewną trudność i niedogodność w przypadku spawania tego typu stali i fakt ten powinien być uwzględniony podczas opracowywania technologii spawania danej konstrukcji. O stopniu odkształcenia decydują m.in. rodzaj zaprojektowanego połączenia (inne odkształcenia będą w konstrukcji spawanej ze spoinami pachwinowymi, a inne w tej samej konstrukcji ze spoinami czołowymi) oraz metoda spawania.

Do spawania stali nierdzewnych stosowane są różne metody spawania. W przypadku spawania cienkich blach, a także konstrukcji odpowiedzialnych, w których wymagana jest wysoka jakość połączeń, najczęściej stosuje się metodę TIG. Metoda ta jednak wprowadza stosunkowo duże ilości ciepła (wysokie energie liniowe spawania), co może prowadzić do znacznych odkształceń spawalniczych [1].

Jedną z metod, która wprowadza stosunkowo małe ilości ciepła do obszaru spawania jest spawanie wiązką laserową. Wiązka laserowa, charakteryzująca się dużą gęstością mocy, pozwala uzyskać spoiny o niedużej objętości, wąskie i głębokie. Uzyskane energie liniowe spawania są wielokrotnie niższe niż w przypadku metody TIG, co przekłada się na znacząco niższe odkształcenia po spawaniu. Niedogodnością stosowania procesu spawania laserowego jest konieczność zapewnienia dokładnego zestawienia ze sobą (bez szczeliny) elementów spawanych, co szczególnie jest utrudnione w przypadku konstrukcji przestrzen-

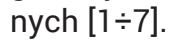

W Instytucie Spawalnictwa podjęto próby nad zastąpieniem technologii spawania TIG złączy teowych ze spoiną pachwinową dwustronną usztywnień paneli kadłuba nośnego silnika lotniczego technologią spawania laserowego bez materiału dodatkowego złączy teowych ze spoiną czołową.

Dr inż. Sebastian Stano - Instytut Spawalnictwa, dr inż. Marcin Zawadzki - Pratt \& Whitney Rzeszów S.A.

Autor korespondencyjny/Corresponding author: sebastian.stano@is.gliwice.pl 


\section{Badania własne}

Celem przeprowadzonych badań było: określenie możliwości zastosowania spawania laserowego bez materiału dodatkowego do wykonania złączy teowych ze spoiną czołową stosowanych w konstrukcji paneli kadłuba nośnego, wykonanie testowych złączy teowych, wyznaczenie przykładowych parametrów spawania, dla których spełnione zostaną wymagania jakościowe określone w specyfikacji producenta kadłuba nośnego oraz wykonanie technologicznych prób spawania laserowego na stanowisku laboratoryjnym panelu kadłuba nośnego.

Kadłub nośny silnika zbudowany jest z kilku pojedynczych paneli (rys. 1) zestawionych ze sobą tak, że po spawaniu tworzą całą cylindryczną osłonę o odpowiednich parametrach. Pojedynczy panel pierwotnie wykonywany był z blachy jako jedna całość o odpowiedniej grubości, zapewniając odpowiednią sztywność i wytrzymałość kadłuba nośnego. Obecnie, ze względu na potrzebę obniżenia masy konstrukcji, panel jest elementem wieloczęściowym, składającym się z cienkiej osłony oraz spawanych do niej żeber usztywniających. Obecnie stosowaną technologią łączenia żeber usztywniających do cienkiej blachy osłony jest ręczne spawanie TIG z materiałem dodatkowym (proces $141 \mathrm{wg}$ PN -EN ISO 4063:2011) - złącza teowe ze spoiną pachwinową. Ze względu na pracochłonność procesu spawania ręcznego oraz brak powtarzalnej jakości tych złączy, podjęto próby wprowadzenia innych nowych metod spawania, które umożliwiłyby uzyskanie powtarzalnej jakości połączeń oraz robotyzację procesu spawania. Jedną z rozważanych koncepcji

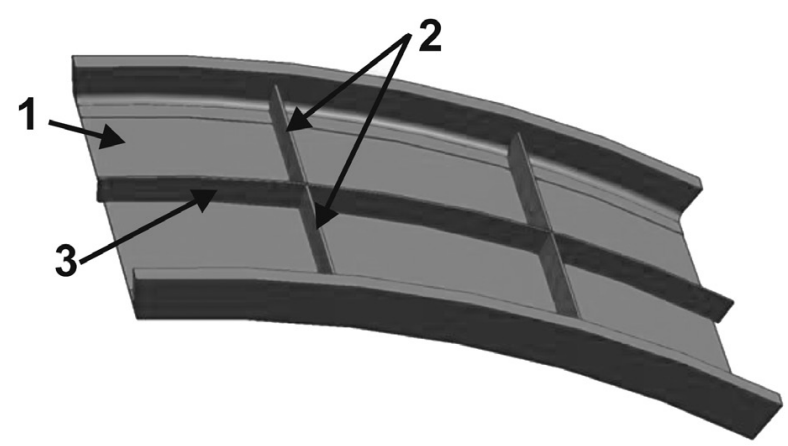

Rys. 1. Schemat panelu stanowiącego fragment kadłuba nośnego: 1 - pas osłony, 2 - żebra usztywniające poprzeczne, 3 - żebra usztywniające wzdłużne

Fig. 1. Scheme of the panel constituting a fragment of the engine casing: 1 - casing panel, 2 - transverse stiffening ribs, 3 - longitudinal stiffening ribs
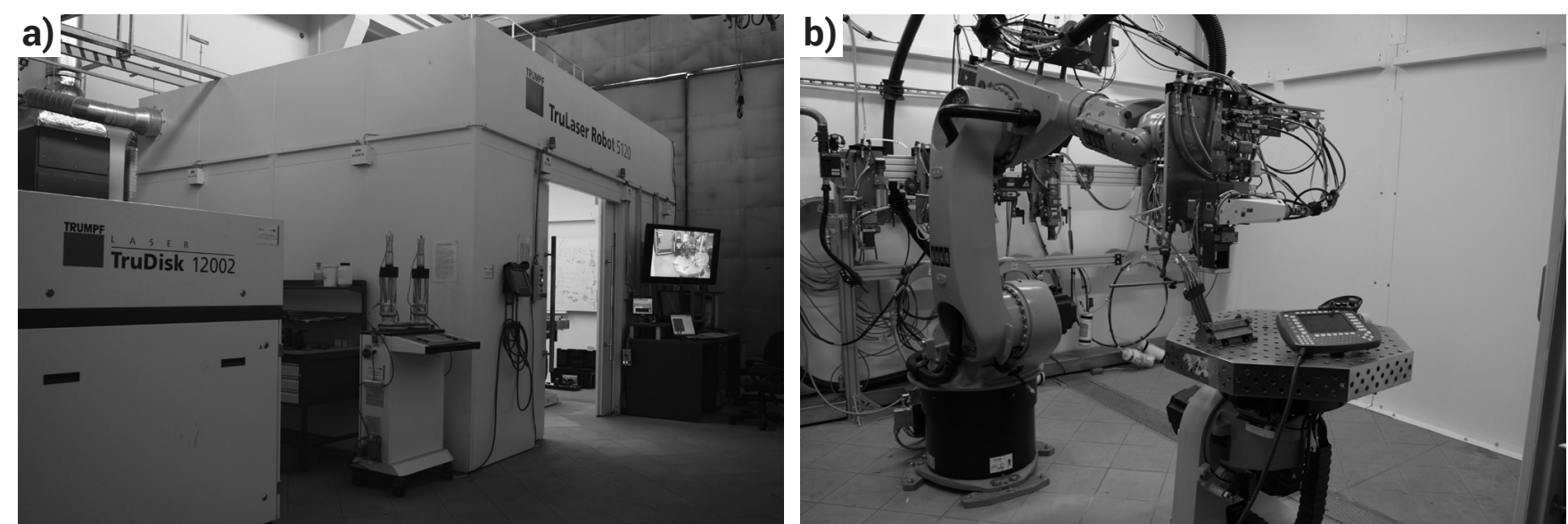

Rys. 2. a) Zrobotyzowane stanowisko do obróbki laserowej z laserem dyskowym TruDisk 12002 o max. mocy 12 kW (a), robot przemysłowy KUKA KR30HA z zamontowaną głowicą spawalniczą CFO stosowaną w badaniach (b)

Fig. 2. Robot laser processing station provided with the TruDisk 12002 disc laser (a), KUKA KR3OHA industrial robot with the CFO welding head (b) 
a)
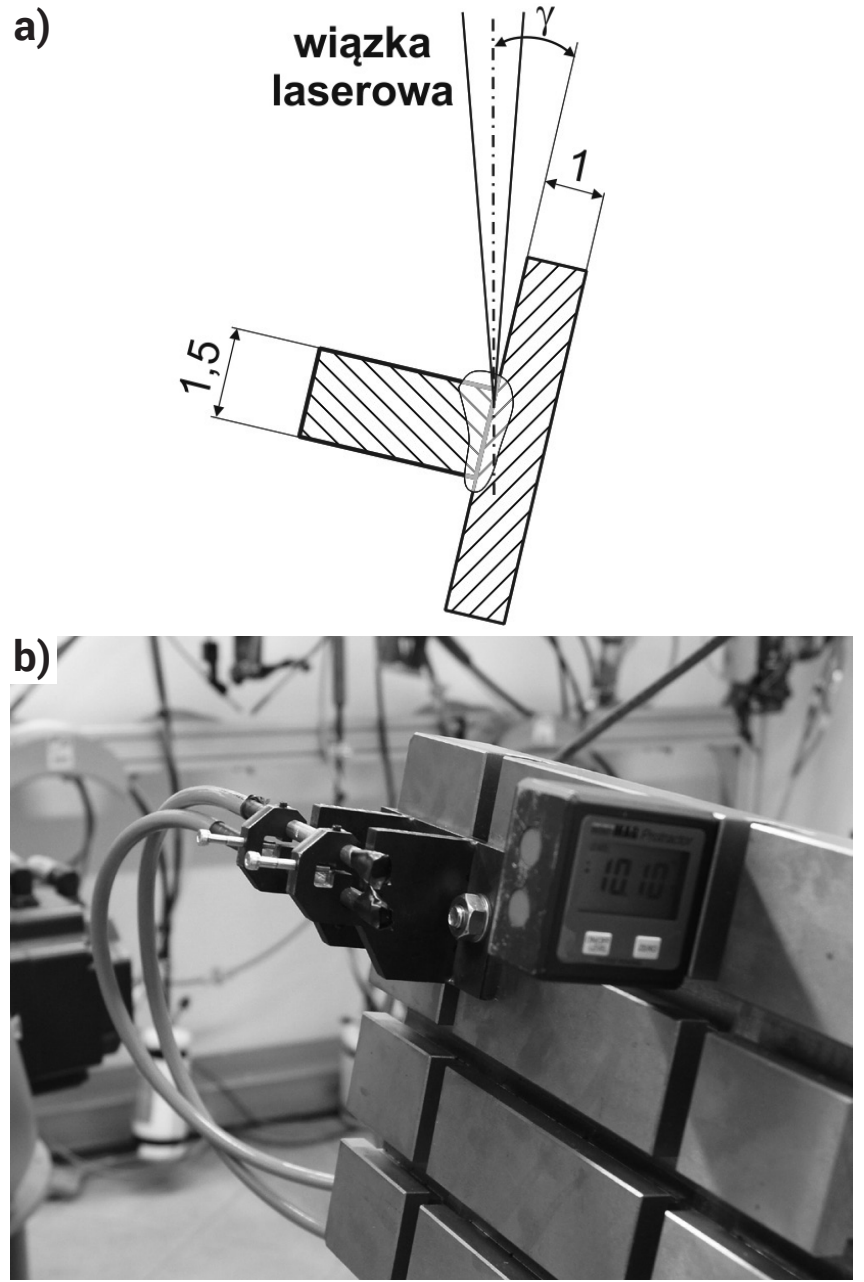

Rys. 3. Schemat procesu spawania elementów próbnych (a) w specjalistycznym przyrządzie ze zintegrowaną osłoną gazową (b)

Fig. 3 Welding of the test elements (a) using the specialist device with the integrated gas shielding system (b)

\section{Analiza i wstępny dobór kąta wejścia wiązki laserowej w obszar styku blach złącza teowego}

Oprócz parametrów związanych bezpośrednio z ilością ciepła wprowadzanego do obszaru złącza, takich jak moc wiązki laserowej, prędkość spawania, gęstość mocy w obszarze oddziaływania wiązki laserowej (stopień jej rozogniskowania), w przypadku spawania złączy teowych, istotnym parametrem jest kąt wejścia wiązki laserowej względem styku łączonych blach. Kąt wejścia wiązki laserowej odpowiada za ukierunkowanie penetracji obszaru złącza. Idealnym rozwiązaniem byłoby uzyskanie kierunku penetracji obszaru złącza wzdłuż krawędzi styku blach (kąt $y=0^{\circ}$ ). Jednakże ze względu na kształt wiązki laserowej w przestrzeni, której krzywe kaustyczne tworzące obwiednie zogniskowanej wiązki laserowej są podobne do ściętego stożka o minimalnej średnicy równej ognisku wiązki laserowej i zależą od zastosowanego rezonatora i optyki laserowej (światłowód i głowica robocza), niezbędny jest dobór odpowiedniego kąta wejścia wiązki laserowej $\gamma$, tak aby uzyskać nadtopienie krawędzi elementów łączonych na całej długości styku łączonych elementów i tym samym poprawną spoinę. Przeprowadzono symulację rysując w skali zarys spawanych elementów oraz teoretyczne krzywe kaustyczne wiązki laserowej o parametrach optycznych takich jak rzeczywista wiązka laserowa stosowana w badaniach (rys. 4). Stwierdzono, że minimalny kąt wejścia wiązki laserowej w obszar styku łączonych blach dla złącza teowego i zastosowanej optyki laserowej wynosi ok. $7^{\circ}$. Takie pozycjonowanie

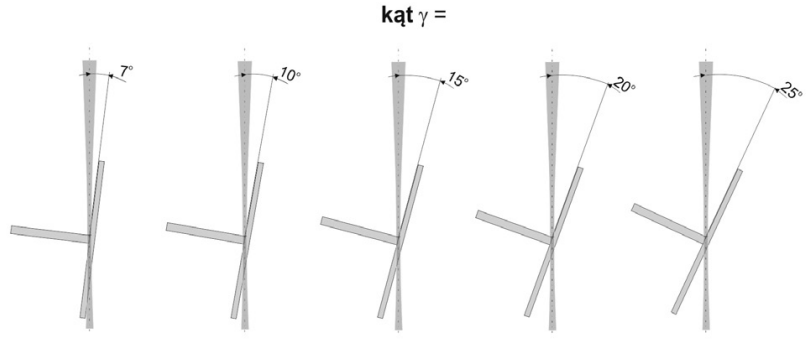

Rys. 4. Symulacja wzajemnego położenia wiązki laserowej i obszaru styku łączonych elementów przy różnym kącie wejścia wiązki laserowej $Y$

Fig. 4 Simulation of the mutual position of the laser beam and the interface of the elements being welded for various values of laser beam insertion angle $y$

wiązki laserowej pozwala na objęcie nią największego obszaru styku łączonych elementów oraz minimalizuje niebezpieczeństwo przetopienia cieńszej blachy osłony sprężarki. Przy takim ustawieniu kąta wejścia w obszar styku wiązki laserowej, jej część obejmuje powierzchnię cieńszej blachy, padając na nią pod bardzo małym kątem. Ta część wiązki laserowej może odbić się od powierzchni blachy, częściowo nadtapiając ją i uszkadzając jej powierzchnię. Wraz ze wzrostem kąta wejścia wiązki laserowej zmienia się kierunek propagacji wiązki laserowej, powodując zwiększoną penetrację wiązki na grubości blachy osłony sprężarki i zwiększone niebezpieczeństwo jej przetopienia. Rozwiązaniem tego problemu może być spawanie dwustronne, ze zmniejszoną mocą i ograniczonym wtopieniem w porównaniu do spawania jednostronnego lub spawanie $z$ odsunięciem wiązki laserowej od linii styku blach w kierunku żebra usztywniającego. Teoretyczna analiza wzajemnego położenia wiązki laserowej oraz styku blach (rys. 4) wykazała, że dla grubości blach stosowanych w badaniach nie powinno być konieczności przesuwania wiązki laserowej od linii styku blach. Przedstawione na rysunku 4 rozważania pokazują jedynie obszar styku blach jaki obejmuje teoretyczna wiązka laserowa. W praktyce wytwarzany jest kanał gazodynamiczny otoczony ciekłym metalem, co zwiększa obszar przetopionego styku blach w porównaniu do obszaru wyznaczonego na rysunku. Stwierdzono, że dla grubości blach stosowanych w badaniach zakres kąta wejścia wiązki laserowej, przy której prognozowane jest uzyskanie pełnego przetopienia styków łączonych blach, jest stosunkowo duży - nawet do ok. $25^{\circ}$.

Minimalny kąt wejścia wiązki laserowej może być ograniczony ze względu na lokalizację spoin na panelu kadłuba nośnego (rys. 5). Na podstawie wykonanych pomiarów stwierdzono, że kąt wejścia wiązki laserowej w przypadku spawania żeber usztywniających poprzecznych (rys. 1) może być ustawiony jako kąt minimalny $7^{\circ}$, dobrany w symulacji. Natomiast minimalny kąt wejścia wiązki laserowej w przypadku spawania żeber usztywniających wzdłużnych

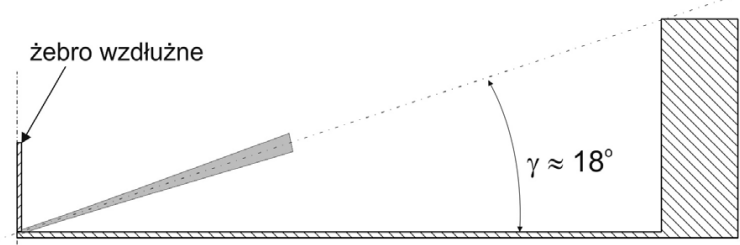

Rys. 5. Ograniczenia minimalnego kąta wejścia wiązki laserowej w obszar styku blachy osłony sprężarki i wzdłużnego żebra usztywniającego, wynikający z konstrukcji osłony sprężarki

Fig. 5. Limitations of the minimum angle of laser beam insertion in the interface area of the compressor casing and the longitudinal stiffening rib resulting from the compressor casing design 
(rys. 1, rys. 5) powinien wynosić powyżej $18^{\circ}$, ze względu na wystającą krawędź na brzegach panelu osłony sprężarki oraz rzeczywiste wymiary ogniskowanej przez układ optyczny wiązki laserowej.

\section{Wpływ mocy i kąta wejścia wiązki laserowej w obszar styku na jakość uzyskanego połączenia}

Wykonano szereg prób spawania laserowego złączy teowych ze spoiną czołową zamocowanych w opracowanym przyrządzie ze zintegrowaną osłoną gazową grani. Na podstawie własnego doświadczenia, przyjęto stałe wartości dla wybranych parametrów procesu:

- prędkość spawania $\mathrm{v}_{\mathrm{s}}=3,5 \mathrm{~m} / \mathrm{min}$;

- położenie ogniska wiązki laserowej (stopień jej rozogniskowania) $f=0 \mathrm{~mm}$ odpowiednie dla zakresu grubości spawanych materiałów (rys. 6);

- przesunięcie wiązki laserowej względem styku łączonych elementów a $=0 \mathrm{~mm}$ (rys. 6).

a)
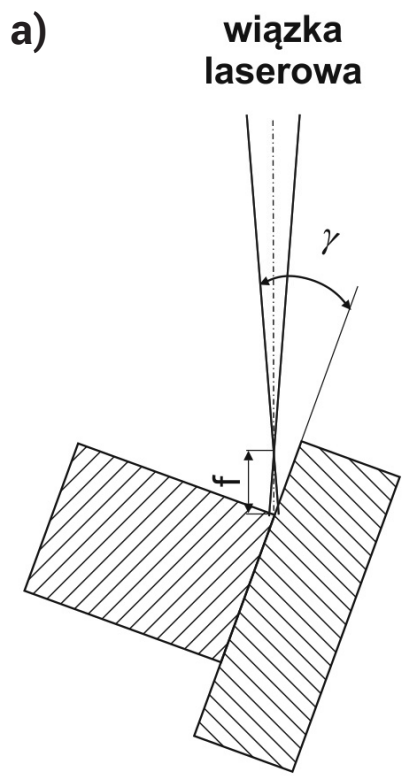

b)

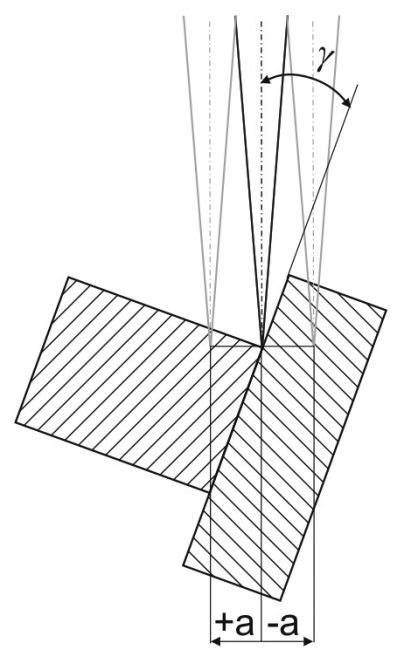

Rys. 6. Wizualizacja parametrów: $f$ - stopnia rozogniskowania wiązki laserowej (a) oraz parametru a - przesunięcia względem styku łączonych elementów (b)

Fig. 6. Visualisation of parameters: $f$ - laser beam defocussing degree (a) and parameter a - shift of the laser beam in relation to the interface of the elements being joined (b)

W trakcie prób technologicznych zmieniano następujące parametry procesu:

- moc wiązki laserowej P [kW] - decyduje o uzyskanej głębokości wtopienia, dobierano tak, aby uzyskać pełne przetopienie;

- kąt wejścia wiązki laserowej w obszar styku łączonych elementów - decyduje o kierunku penetracji i kształcie spoiny.

Dla dobranych parametrów procesu spawania wykonano próby spawania złączy teowych ze spoiną czołową jednostronną i dwustronną, dla różnych kątów wejścia wiązki laserowej. W tablicach I i II zestawiono parametry spawania laserowego, a makrostruktury spoin na rysunku 7.

Badania wizualne uzyskanych połączeń wykonane okiem nieuzbrojonym oraz za pomocą lupy o powiększeniu 10x nie wykazały występowanie niezgodności spawalniczych zgodnie z PN-EN 13919 1: 2002 [8]. Od strony lica spoiny zaobserwowano przebarwienia, świadczące o miejscowym, chwilowym zaburzeniu osłony gazowej w trakcie procesu
Tablica I. Parametry procesu spawania laserowego złączy teowych ze spoiną czołową jednostronną złączy próbnych symulujących połączenie żebra usztywniającego z pasem panelu

Table I. Process parameters concerning the laser welding of the Tjoints with the one-sided butt weld simulating the joint of the stiffening rib and the casing panel

\begin{tabular}{|c|c|c|c|}
\hline Nr złącza & Kąt $\mathbf{~ [ { } ^ { \circ } ]}$ & Moc $\mathbf{P}[\mathbf{W}]$ & $\begin{array}{c}\text { Prędkość spawania } \\
\mathbf{v}_{\mathbf{s}} \text { [m/min] }\end{array}$ \\
\hline 5 & 7 & 1850 & 3,5 \\
\hline 22 & 10 & 2100 & 3,5 \\
\hline 31 & 15 & 2100 & 3,5 \\
\hline
\end{tabular}

Tablica II. Parametry procesu spawania laserowego złączy teowych ze spoiną czołową dwustronną złączy próbnych symulujących połączenie żebra usztywniającego z pasem osłony

Table II. Process parameters concerning the laser welding of the T-joints with the two-sided butt weld simulating the joint of the stiffening rib and the casing panel

\begin{tabular}{|c|c|c|c|}
\hline Nr złącza & Kąt $\mathbf{~ [ { } ^ { \circ } ]}$ & Moc $\mathbf{P}[\mathbf{W}]$ & $\begin{array}{c}\text { Prędkość spawania } \\
\mathbf{v}_{\mathbf{s}} \text { [m/min] }\end{array}$ \\
\hline 7 & 7 & 1100 & 3,5 \\
\hline 24 & 10 & 1400 & 3,5 \\
\hline 33 & 15 & 1400 & 3,5 \\
\hline 64 & 20 & 1400 & 3,5 \\
\hline
\end{tabular}

spawania. W procesie spawania, przy ustawionym kącie wejścia wiązki laserowej od $7^{\circ}$ do $15^{\circ}$ zaobserwowano ślady nadtopienia powierzchni blachy reprezentującej osłonę sprężarki przez część wiązki laserowej padającej na tę powierzchnię pod niewielkim kątem. Wraz ze wzrostem kąta wejścia wiązki laserowej ślad był coraz mniejszy.

Pełna weryfikacja jakości uzyskanych połączeń możliwa była dopiero po analizie makrostruktury i wykonaniu pomiarów ewentualnych wielkości charakterystycznych niezgodności. Analiza zdjęć makrograficznych wykonanych połączeń wykazała występowanie niewielkich podtopień (501 - podtopienie wg PN-EN13919-1:2002) oraz niewielkie deformacje cieńszej blachy symulującej pas panelu kadłuba nośnego. Odkształcenia te są niewielkie i w przypadku spawania całej, sztywniejszej konstrukcji będą one znacznie mniejsze.

Na podstawie pomiarów wielkości podtopień powstałych w procesie spawania laserowego stwierdzono, że zastosowanie spawania dwustronnego zmniejsza prawdopodobieństwo powstania podtopień, których wymiar charakterystyczny przekroczy wymagania poziomu jakości B wg PN-EN ISO 13919-1. Największą głębokość podtopienia zmierzono dla spoin jednostronnych - złącza nr 5, 22 i 31 (tabl. III). Najmniejsze podtopienia zmierzono dla spoiny dwustronnej wykonanej z ustawieniem wiązki laserowej pod kątem $15^{\circ}$ do powierzchni blachy osłony. Ze względu na konstrukcję kadłuba nośnego kąt $15^{\circ}$ jest kątem zbyt małym w przypadku spawania żeber usztywniających wzdłużnych (rys. 1).

Zwiększenie kąta wejścia wiązki laserowej do $20^{\circ}$ skutkowało przekroczeniem wielkości charakterystycznej $h_{2}-$ jednego z podtopień od strony pasa osłony o 0,09 mm powyżej maksymalnego poziomu dopuszczalnego dla wymagań ostrych B wg PN-EN ISO 13919 (złączę nr 64, tabl. III). Pozostałe wielkości podtopień mieściły się w poziomie jakości B. 
$\mathrm{Nr}$ złącza 5,

kąt $Y=7^{\circ}$, jednostronna

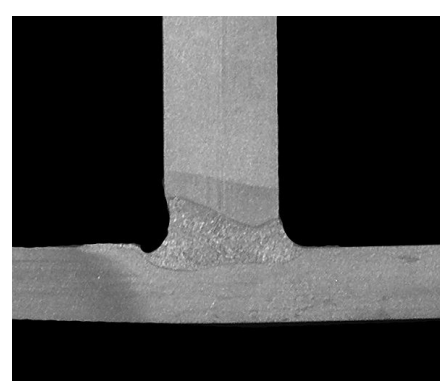

$\mathrm{Nr}$ złącza 31

kąt $Y=15^{\circ}$, jednostronna

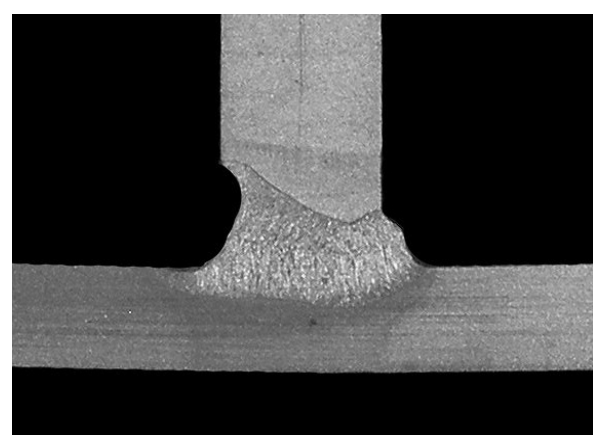

$\mathrm{Nr}$ złącza 7 , kąt $Y=7^{\circ}$, dwustronna

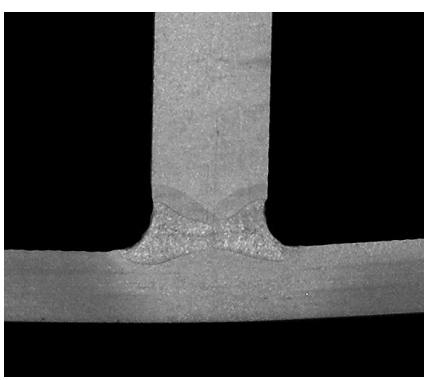

$\mathrm{Nr}$ złącza 33,

kąt $\mathrm{Y}=15^{\circ}$, dwustronna
Nr złącza 22, kąt $y=10^{\circ}$, jednostronna

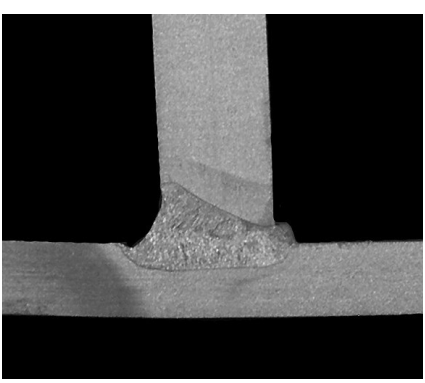

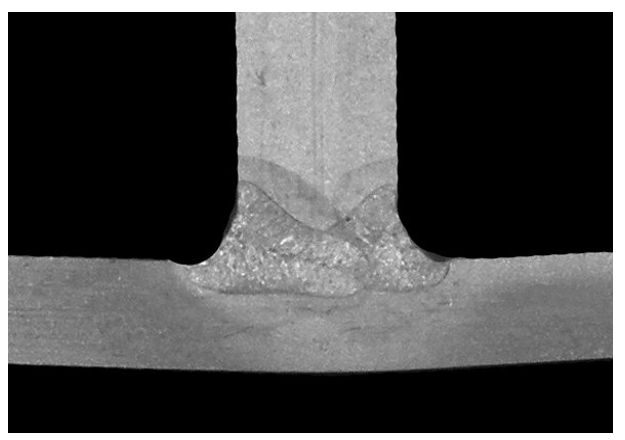

$\mathrm{Nr}$ złącza 24,

kąt $Y=10^{\circ}$, dwustronna

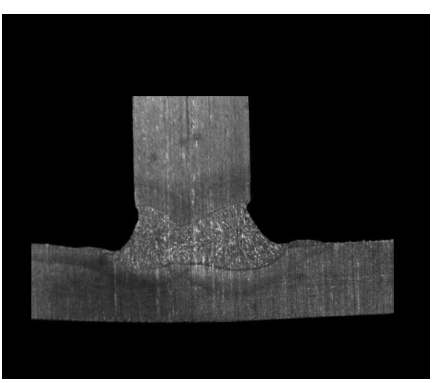

$\mathrm{Nr}$ złącza 64, kąt $Y=20^{\circ}$, dwustronna

Rys. 7. Makrostruktury teowych jednostronnych i dwustronnych złączy doczołowych spawanych laserem przy różnym kącie ustawienia wiązki laserowej

Fig. 7. The macrostructure of the one-side and two-side welded butt T-joint made using a laser beam with different insertion angle

Tablica III. Wyniki pomiarów wielkości charakterystycznej niezgodności podtopienia wg PN EN ISO 13919-1:2002 dla złączy teowych spawanych laserem

Table III. Measurement results concerning the characteristic quantity (undercut) according to PN EN ISO 13919-1:2002 for the laser-welded T-joints

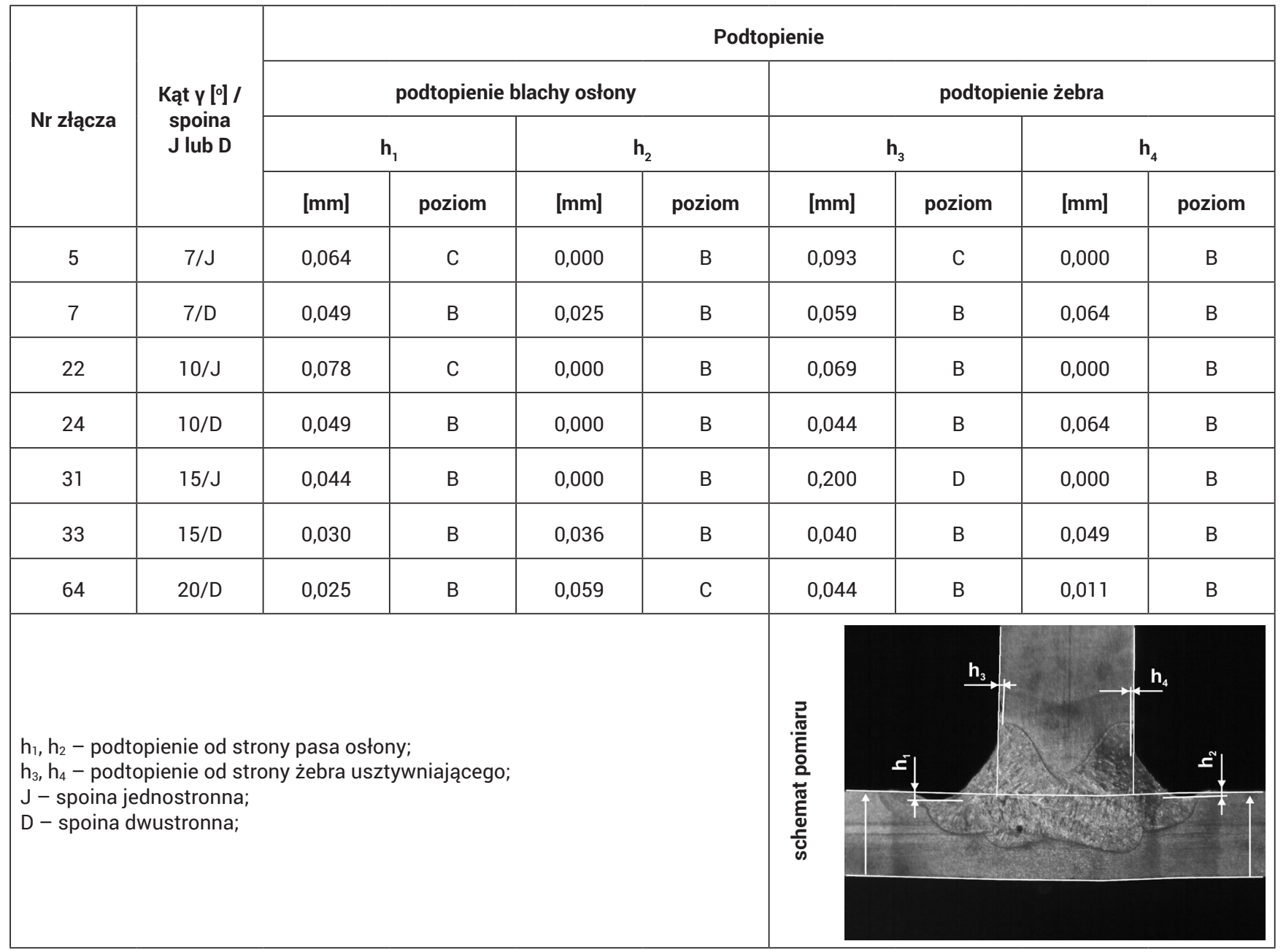


Wpływ przesunięcia „a” względem styku łączonych elementów na jakość uzyskanych spoin

Ze względu na ślady uszkodzenia powierzchni blachy imitującej panel kadłuba nośnego przez wiązkę laserową oraz analizując kształt uzyskanych przetopień (szerokość lica i grani wtopienia przy spawaniu jednostronnym) podjęto decyzje o wykonaniu prób spawania z przesunięciem wiązki laserowej względem styku łączonych blach (rys. 6b). Przesunięcie wiązki laserowej względem styku łączonych elementów (zmiana parametru „a”) może skutkować zmniejszeniem się podtopień, szczególnie w przypadku odsunięcia wiązki laserowej od powierzchni blachy osłony (kierunek „a+").

Wykonano próby spawania laserowego złączy teowych ze spoiną czołową dwustronną, zmieniając parametr "a" w zakresie od -0,4 mm do +0,6 mm, co 0,2 mm.

Makrostruktury uzyskanych połączeń pokazano na rysunku 8, a wyniki pomiarów podtopień wg PN EN ISO 13919-1 zestawiono w tablicy IV.

Wyniki prób spawania dla różnego poziomu parametru „a" wykazały, że ze względu na wielkość podtopień od strony blachy panelu kadłuba nośnego nie jest wskazane stosowanie przesunięcia wiązki laserowej w kierunku blachy panelu kadłuba nośnego (ujemne wartości parametru „a”). Dla przesunięcia $a=-0,4 \mathrm{~mm}$, wiązka laserowa padająca pod kątem $20^{\circ}$ do powierzchni blachy panelu kadłuba nośnego powoduje powstanie podtopień o głębokości przekraczającej 15\% grubości blachy, a więc niespełniające wymagań łagodnych $D$ dla niezgodności podtopienie wg PN EN ISO 13919-1 (złącze nr 77 tabl. IV, rys. 8). Wraz ze wzrostem wartości parametru „a” (przesuwaniem wiązki laserowej w kierunku blachy żebra usztywniającego) wartość zmierzonych podtopień maleje. Najkorzystniejsze wartości wymiarów charakterystycznych dla niezgodności podtopienie zmierzono dla parametru $\mathrm{a}=+0,2 \mathrm{~mm} \mathrm{i}+0,4 \mathrm{~mm}$. Przesunięcie wiązki laserowej o wielkość $a=+0,6 \mathrm{~mm}$ spowodowało pojawienie się podtopienia nieznacznie przekraczającego wartość dopuszczalną dla wymagań ostrych, które zaklasyfikowanego do poziomu jakości C. Równocześnie analiza makrostruktury tego połączenia ( $\mathrm{nr} 75$, rys. 8) pokazała, że dalsze przemieszczanie wiązki w kierunku blachy żebra usztywniającego może spowodować pojawieniem się braku przetopu w środkowej części złącza.

Równocześnie stwierdzono, że zastosowana moc wiązki laserowej $1400 \mathrm{~W}$, przy dodatnich wartościach parametru „a", może spowodować uzyskanie miejscowego pełnego przetopu, z bardzo wąską, delikatną granią, bez podtopień od strony lica. Tak więc zastosowana moc wiązki laserowej $1400 \mathrm{~W}$ jest wartością graniczną (dla stosowanego w badaniach źródła laserowego oraz głowicy optycznej), powyżej której występuje proces spawania jednostronnego, skutkujący niebezpieczeństwem powstawania podtopień lica spoiny.

Z drugiej strony, zbyt mała moc wiązki laserowej może spowodować, że wystąpią zakłócenia z formowaniem się kanału gazodynamicznego w procesie spawania laserowego, powodujące, że kształt uzyskanej spoiny zmieni się z głębokiej i wąskiej (charakterystycznej dla procesu spawania laserowego techniką z oczkiem) na płytszą i szerszą (zbliżoną do spoin uzyskiwanych w procesie spawania laserowego techniką z jeziorkiem). W konsekwencji może wystąpić problem z uzyskaniem powtarzalności pełnego przetopu wzdłuż styku elementów łączonych. Graniczną wartością mocy dla zastosowanego układu optycznego była moc 1200 W, dla której losowo uzyskiwano przetop lub brak przetopu (rys. 9).

W celu weryfikacji dobranych parametrów spawania wykonano serię siedmiu prób spawania ze stałymi ustawieniami parametrów. Moc wiązki laserowej ustawiono na poziomie $1,3 \mathrm{~kW}$, a parametr "a" na poziomie $+0,3 \mathrm{~mm}$. Ustawienie parametru „a" na poziomie $+0,3 \mathrm{~mm}$ - środkowe położenie z badanego i wybranego zakresu zmienności parametru „a", miało na celu skompensować ewentualne błędy powtarzalności pozycjonowania robota przemysłowego. $\mathrm{nr} 77, \mathrm{a}=-0,4 \mathrm{~mm}$

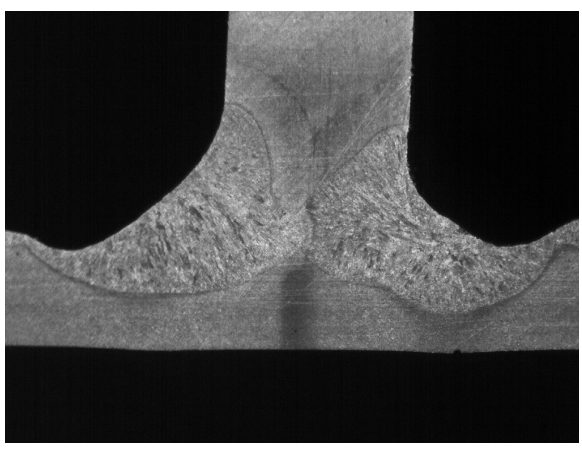

$\mathrm{nr} 73, \mathrm{a}=+0,2 \mathrm{~mm}$

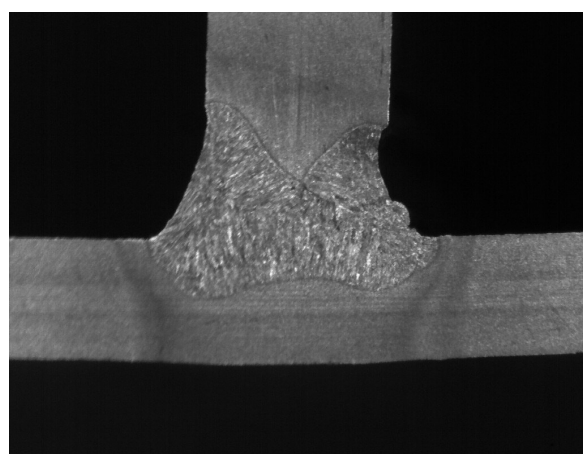

$\mathrm{nr} 76, \mathrm{a}=-0,2 \mathrm{~mm}$

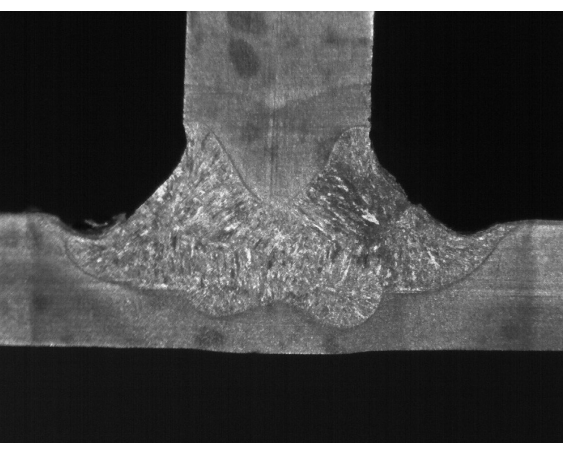

$\mathrm{nr} 74, \mathrm{a}=+0,4 \mathrm{~mm}$

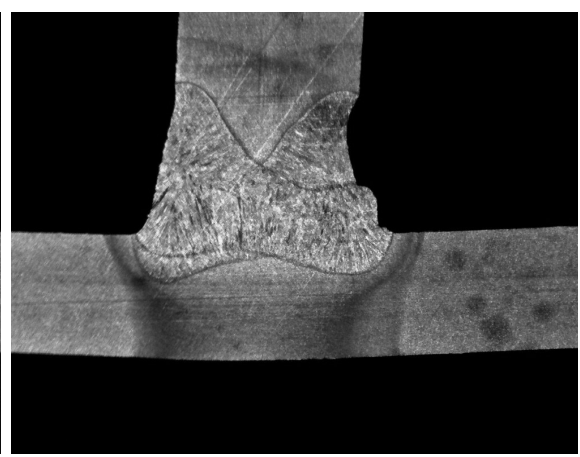

$\mathrm{nr} 71, \mathrm{a}=0,0 \mathrm{~mm}$

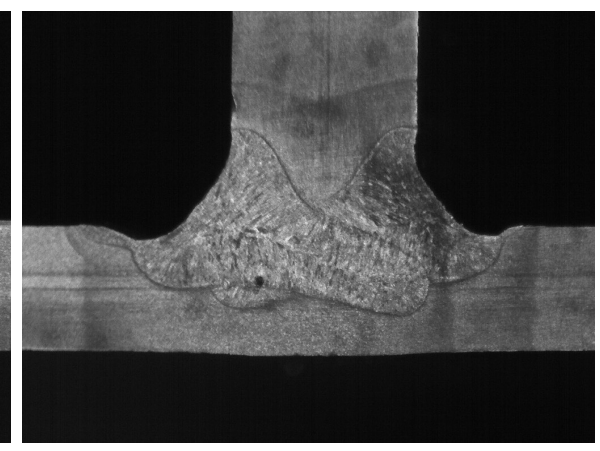

$\mathrm{nr} 75, \mathrm{a}=+0,6 \mathrm{~mm}$

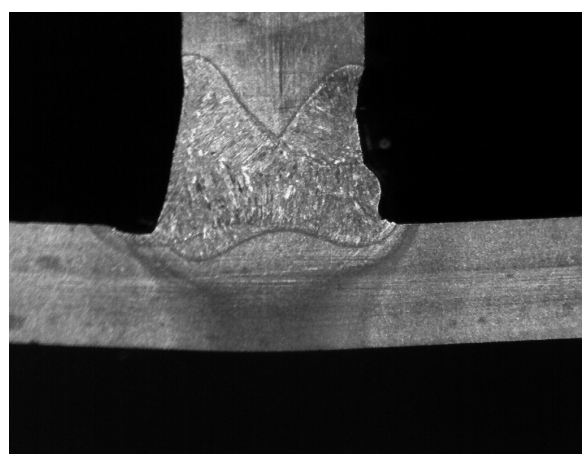

Rys. 8. Makrostruktura złączy teowych spawanych laserem przy różnym ustawieniu parametru „a” (rys. 6b)

Fig. 8. Macrostructure of the T-joints made using laser welding and various values of parameter "a" (Fig. 6b) 
Tablica IV. Wynik pomiarów podtopień zgodnie z PN-EN 13919-1 w złączach teowych spawanych laserem przy różnym parametrze „a” Table IV. Undercut-related measurement results in accordance with PN-EN 13919-1 in the T-joints made using laser welding and various values of parameter "a"

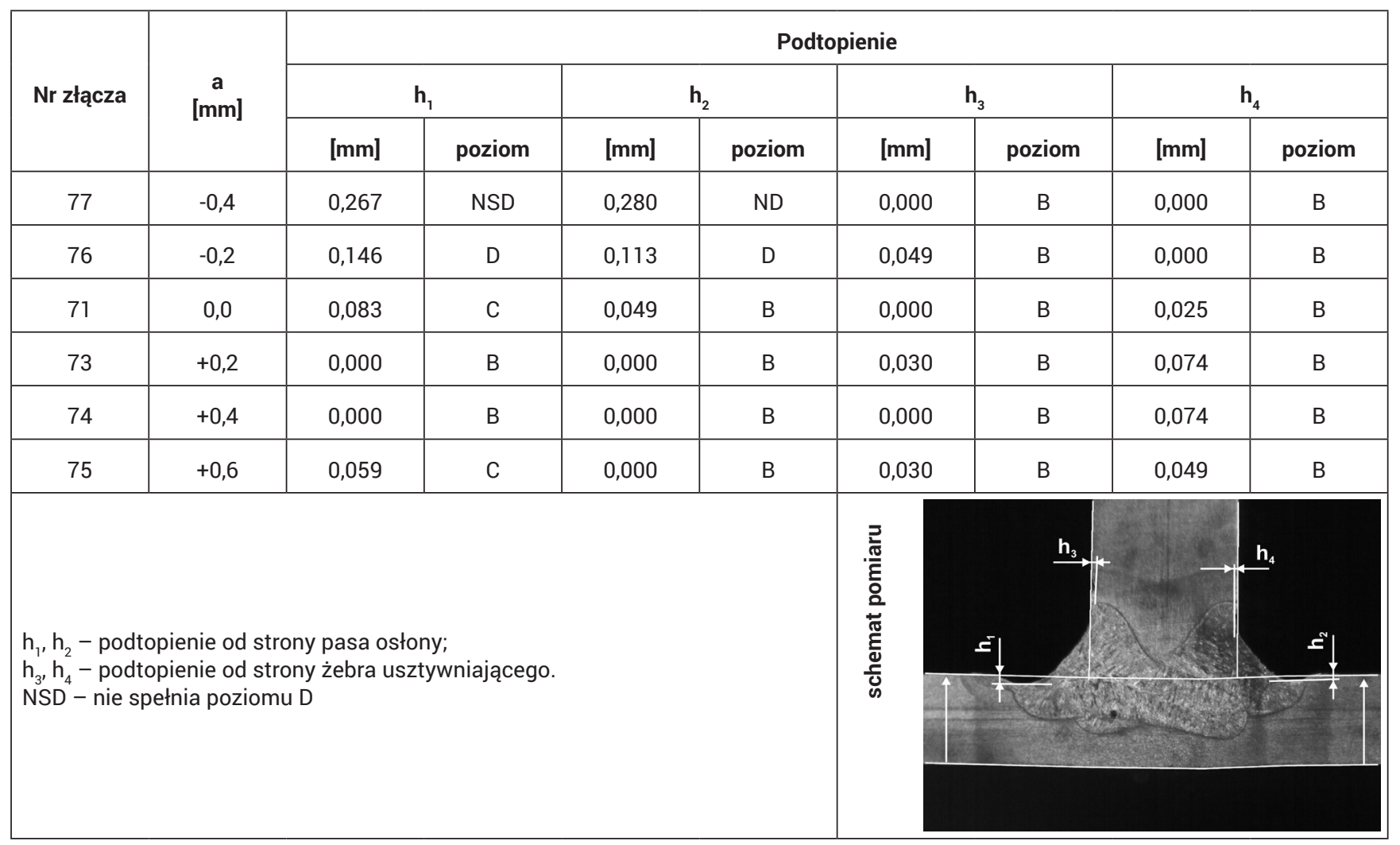
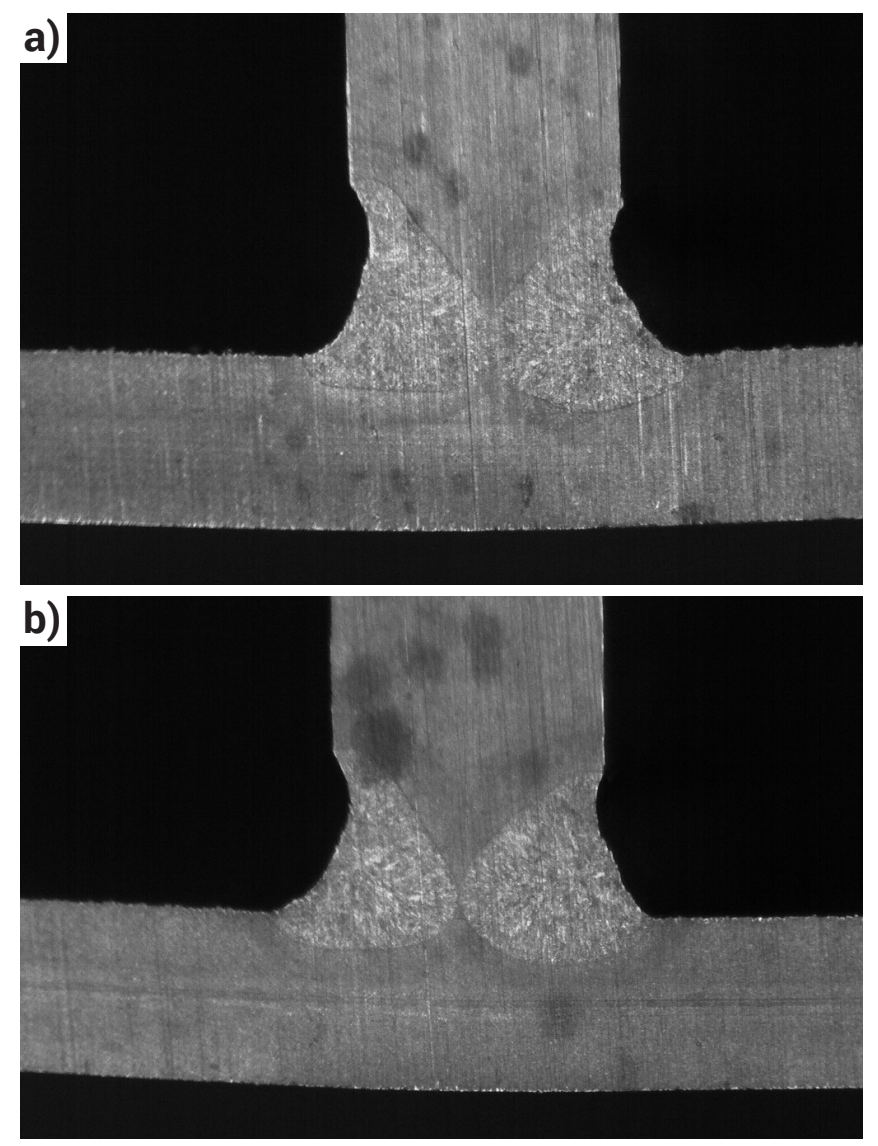

Rys. 9. Makrostruktury złączy spawanych laserem przy obniżonej mocy wiązki laserowej do poziomu $1200 \mathrm{~W}$ : a - złącze z pełnym przetopem, b - złącze bez pełnego przetopu.

Fig. 9. Macrostructures of joints made using a reduced laser beam power of $1200 \mathrm{~W}: \mathrm{a}$ - joint with full penetration, $\mathrm{b}$ - joint without full penetration
Makrostruktury złączy spawanych zestawiono na rysunku 10. Pomiary wymiarów charakterystycznych dla niezgodności podtopienia wg PN-EN13919-1 zestawiono w tablicy V.

Przeprowadzone próby spawania potwierdziły powtarzalność procesu spawania dla systemu laserowego, jaki zastosowano w badaniach (źródło laserowe, głowica technologiczna, manipulator). Dla każdego z siedmiu złączy spawanych nie odnotowano podtopienia od strony blachy osłony sprężarki. Stwierdzono występowanie podtopień od strony żebra - w jednym przypadku wartość zmierzona wymiaru charakterystycznego dla niezgodności podtopienie przekroczyła wartość wymaganą dla poziomu jakości B i sklasyfikowano ją do poziomu jakości C.

\section{Próby spawania rzeczywistego panelu kadłuba nośnego}

Próby spawania wykonane w skali laboratoryjnej nie brały pod uwagę dokładności przygotowania i zestawienia elementów do spawania. Obecnie elementy usztywnienia panelu kadłuba nośnego spawane są metodą TIG. Dla tego procesu spawania dokładność zestawienia elementów do spawania - wielkość szczeliny pomiędzy łączonymi elementami - jest znacząco różna niż w przypadku spawania laserowego. Blachy do spawania laserem, bez materiału dodatkowego, powinny być zestawione bez szczeliny lub ewentualna szczelina nie powinna przekraczać $0,1 \mathrm{~mm}$.

Zachowanie takich wysokich dokładności zestawienia elementów do spawania, tym bardziej w konstrukcji 3D może być utrudnione.

Do prób spawania laserowego przygotowano panel kadłuba nośnego oraz elementy usztywnienia z wykorzystaniem dotychczasowych technologii i sposobów dostępnych w zakładzie, starając się uzyskać ich jak najlepsze zestawienie. 

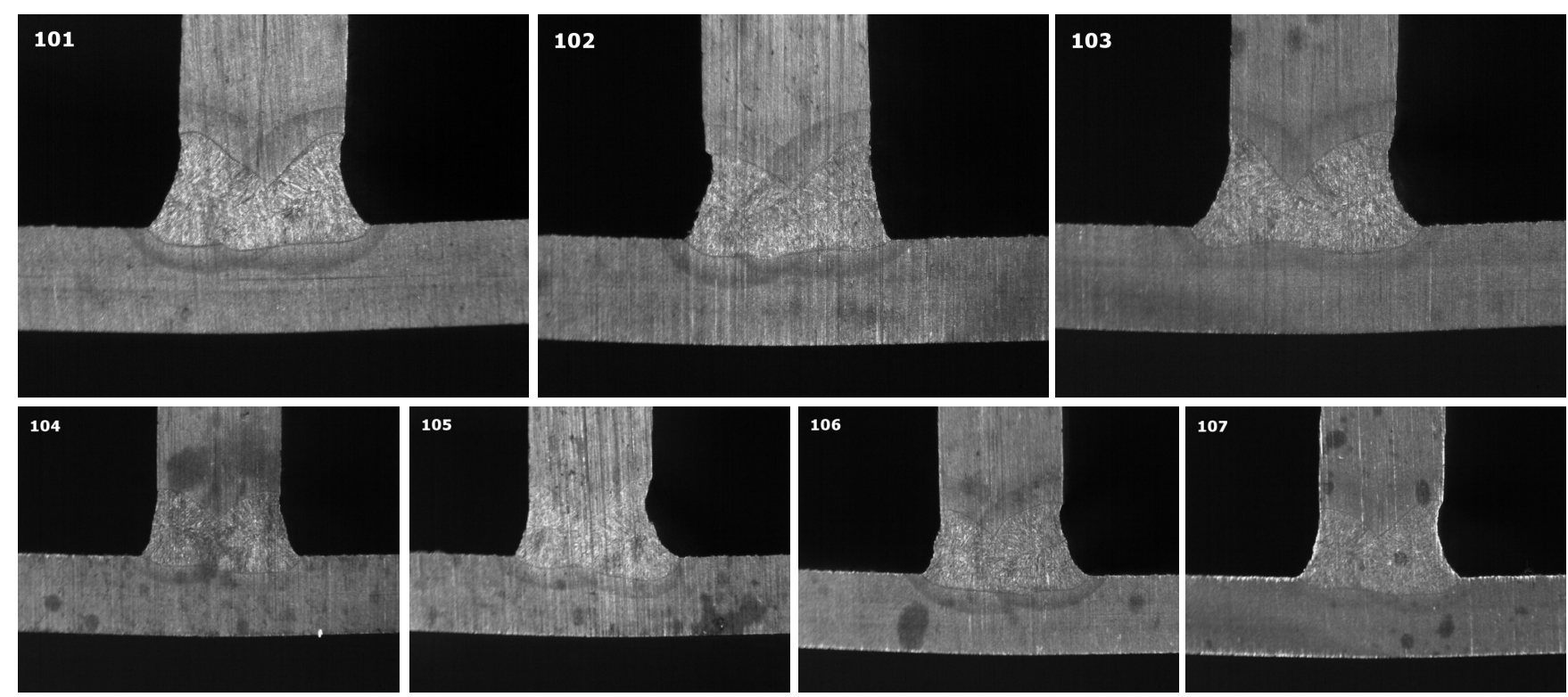

Rys. 10. Makrostruktury złączy teowych żebra usztywniającego $z$ pasem osłony sprężarki spawanych laserem. $P=1,3 \mathrm{~kW}, \mathrm{v}=3,5 \mathrm{~m} / \mathrm{min}$, $y=20^{\circ}, f=0 \mathrm{~mm}, \mathrm{a}=+0,3 \mathrm{~mm}$

Fig. 10. Macrostructures of the laser-welded T-joints of the stiffening rib with the compressor casing panel. $P=1.3 \mathrm{~kW}, \mathrm{v}=3.5 \mathrm{~m} / \mathrm{min}$, $Y=20^{\circ}, f=0 \mathrm{~mm}, a=+0.3 \mathrm{~mm}$

Tablica V. Wynik pomiarów podtopień zgodnie z PN-EN 13919-1 w złączach teowych spawanych laserem przy różnym parametrze „a” Table V. Undercut-related measurement results in accordance with PN-EN 13919-1 in the T-joints made using laser welding and various values of parameter "a"

\begin{tabular}{|c|c|c|c|c|c|c|c|c|}
\hline \multirow{3}{*}{ Nr złącza } & \multicolumn{8}{|c|}{ Podtopienie } \\
\hline & \multicolumn{2}{|c|}{$h_{1}$} & \multicolumn{2}{|c|}{$\mathbf{h}_{2}$} & \multicolumn{2}{|c|}{$\mathrm{h}_{3}$} & \multicolumn{2}{|c|}{$\mathrm{h}_{4}$} \\
\hline & [mm] & poziom & [mm] & poziom & [mm] & poziom & [mm] & poziom \\
\hline 101 & 0,000 & B & 0,000 & B & 0,020 & B & 0,040 & B \\
\hline 102 & 0,000 & B & 0,000 & B & 0,073 & B & 0,000 & B \\
\hline 103 & 0,000 & B & 0,000 & B & 0,015 & B & 0,073 & B \\
\hline 104 & 0,000 & B & 0,000 & B & 0,000 & B & 0,000 & B \\
\hline 105 & 0,000 & B & 0,000 & B & 0,000 & B & 0,097 & C \\
\hline 106 & 0,000 & B & 0,000 & B & 0,000 & B & 0,034 & B \\
\hline 107 & 0,000 & B & 0,000 & B & 0,025 & B & 0,073 & B \\
\hline
\end{tabular}

Spasowanie żebra usztywniającego wzdłużnego do blachy panelu kadłuba nośnego było bardzo dobre. Wizualnie nie stwierdzono szczeliny pomiędzy łączonymi elementami. Po sczepieniu detalu, na podstawie pomiaru szczeliny za pomocą szczelinomierza stwierdzono, że szczelina pomiędzy łączonymi elementami jest mniejsza niż 0,05 mm.

Zestawienie pasa osłony z żebrami usztywniającymi poprzecznymi wykazało, że niemal na całej długości połączenia występuje szczelina, której wartość nie była stała. Żebra usztywniające poprzeczne zostały przygotowane w ten sposób, że od strony krawędzi blachy panelu kadłuba nośnego zastosowano ścięcie naroża umożliwiające przeprowadzenie spawania laserowego na całej długości żebra. Dodatkowo, przy ściętym narożu, zmniejszono wysokość żebra (rys. 11a) tak, aby występujący w pobliżu krawędzi osłony nadlew spoiny łączący blachę panelu z wyprofilowanym pierścieniem panelu (rys. 11b), nie przeszkadzał w zestawieniu żebra usztywniającego z blachą panelu. Powstała $w$ ten sposób szczelina była stosunkowo duża. Po sczepieniu, przed spawaniem wykonano pomiar szczeliny w tym miejscu za pomocą szczelinomierza.

Do sczepiania żeber usztywniających zastosowano wiązkę laserową emitowaną z tego samego urządzenia oraz z tej samej głowicy spawalniczej, co w procesie spawania laserowego. Ustawiono impulsowy tryb spawania. Pojedynczy impuls prostokątny (moc wiązki laserowej $\mathrm{P}=600 \mathrm{~W}$, czas trwania impulsu $\mathrm{T}=12 \mathrm{~ms}$ ) był wykorzystany do utworzenia pojedynczej spoiny punktowej. Spoina sczepna składała się z 3 spoin punktowych zachodzących na siebie.

Po sczepieniu całej konstrukcji dokonano pomiaru za pomocą szczelinomierza szczelin pomiędzy żebrami usztywniającymi a blachą panelu. Wyniki pomiarów szczelin zaznaczono na pasie osłony w pobliżu złącza spawanego, tak aby można było zlokalizować w każdym punkcie złącza 

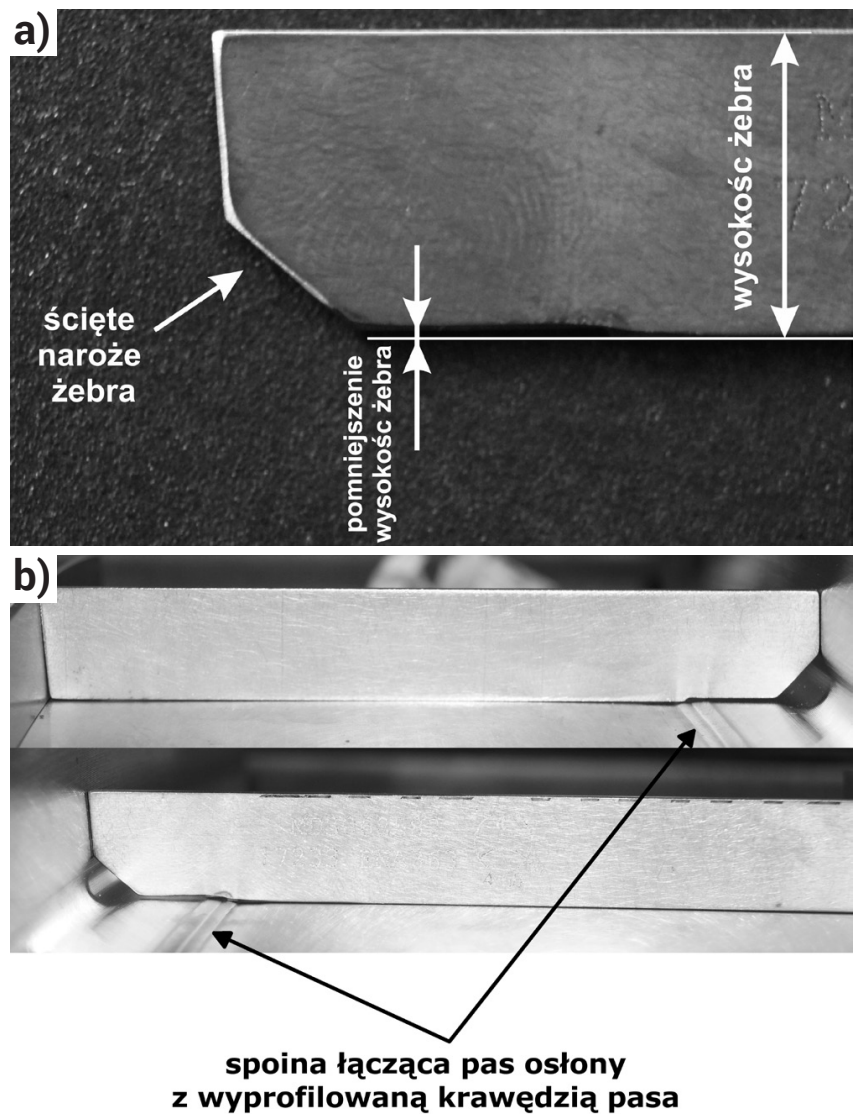

Rys. 11. Sposób przygotowania żebra poprzecznego (a) oraz przykładowe spasowanie żeber poprzecznych z pasem osłony (b)

Fig. 11. Manner of transverse rib preparation (a) and the exemplary matching of the transverse ribs with the casing panel (b)

zakres zmienności szczeliny (rys. 12). W ten sposób na elemencie testowym można zaobserwować wpływ wielkości szczeliny pomiędzy łączonymi elementami na jakości uzyskanych spoin oraz odpowiednio zlokalizować miejsce do ewentualnych, późniejszych badań makroskopowych.

Jako system osłony gazowej lica spoiny zastosowano dwie wielorurkowe dysze gazowe (rys. 13a), każdorazowo ustawiane do wykonania kolejnych spoin. Wiązkę laserową ogniskowano z przesunięciem $\mathrm{a}=0,3 \mathrm{~mm}$ w kierunku żebra usztywniającego (rys. 13b).

Proces spawania laserowego żeber usztywniających z pasem osłony sprężarki przebiegał w sposób stabilny. W czasie

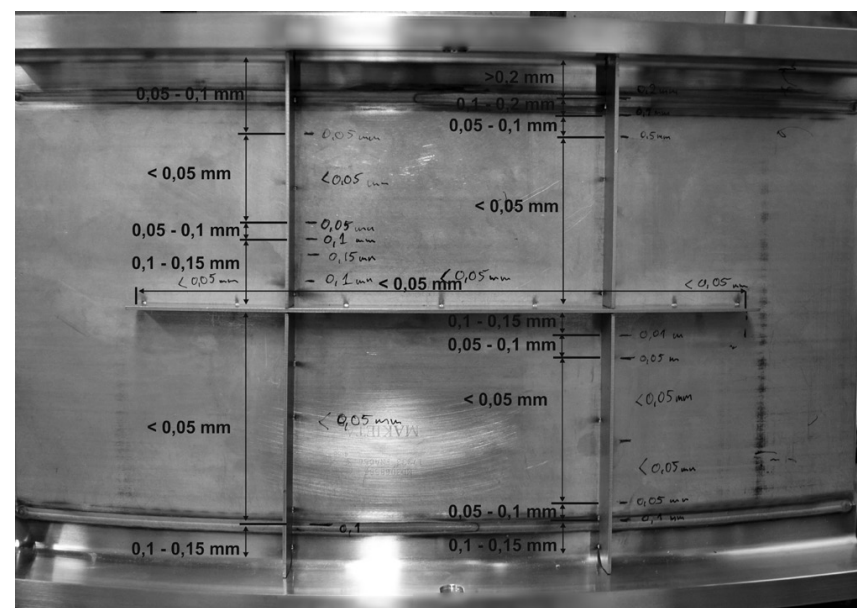

Rys. 12. Element panelu kadłuba nośnego przygotowany do spawania laserowego, z zaznaczonymi wartościami zmierzonej szczeliny w poszczególnych obszarach złącza

Fig. 12. Panel casing element prepared for laser welding, with the marked values of gaps sizes in the individual areas of the joint
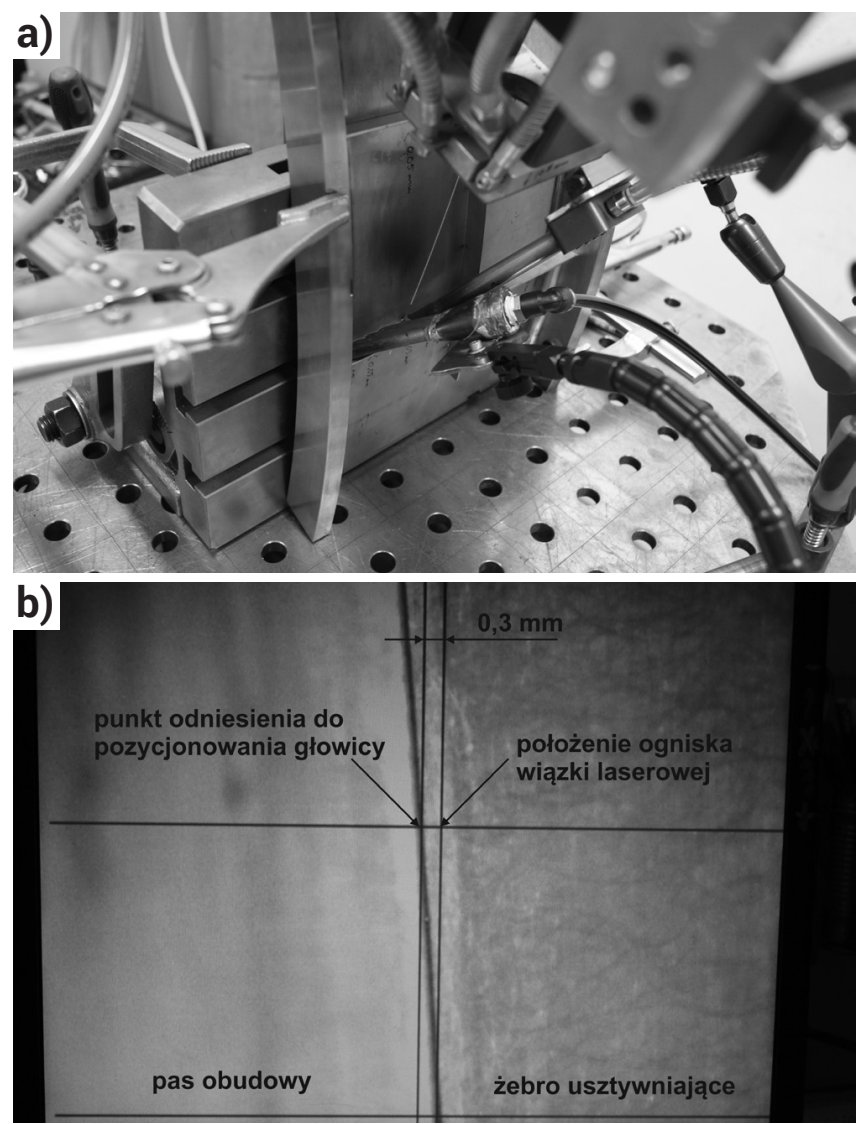

Rys.13. Przygotowany do spawania fragment panelu kadłuba nośnego z żebrami usztywniającymi z dyszami gazu osłonowego podczas spawania żebra usztywniającego poprzecznego (a), sposób pozycjonowania głowicy laserowej (b)

Fig.13. Fragment of the casing panel with the stiffening ribs prepared for welding and the position of the shielding gas nozzle (a), manner of laser beam positioning (b)

spawania nie zaobserwowano rozprysku, czy istotnych zmian w tworzącym się obłoku plazmowym (obserwacja z wykorzystaniem standardowej kamery przemysłowej). Po procesie spawania w obszarze złącza pojawiał się charakterystyczny dla procesu spawania laserowego, łatwousuwalny, czarny osad. Zaobserwowano, że w obszarze złącza, gdzie szczelina pomiędzy żebrem usztywniającym a blachą panelu przekraczała 0,1 mm, pojawiły się zakłócenia procesu, które w skrajnym przypadku prowadziły do braku ciągłości

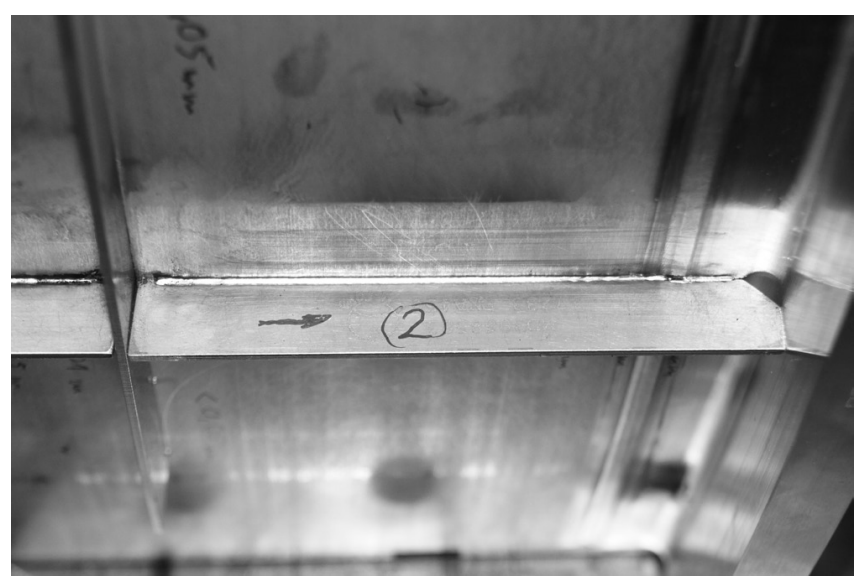

Rys. 14. Przykładowe braki ciągłości spoin w złączach usztywnień poprzecznych z blachą panelu spawanych laserem w miejscu występowania spoin panelu kadłuba nośnego

Fig. 14. Exemplary lack of weld continuity in the laser welded joints of the transverse stiffening ribs with the casing panel in the area of the structural welds of the casing panel 
spoiny. Najbardziej newralgicznym miejscem złącza narażonym na pojawienie się przepaleń był obszar w pobliżu brzegu blachy panelu - miejsce, w którym żebro usztywniające nachodzi na wcześniej wykonaną spoinę (rys. 14). Nie wykonano pomiaru ewentualnie występujących podtopień. Podtopienia te mogą być zaobserwowane i dokładnie pomierzone tylko na zgładzie metalograficznym.
Ilość ciepła wprowadzona do konstrukcji spawanej była stosunkowa nieduża, w porównaniu do przedstawionych przez Pratt \& Whitney Rzeszów elementów spawanych metodą TIG. Od strony wewnętrznej spawanego panelu kadłuba nośnego zaobserwowano niewielkie przebarwienia, które można wyeliminować poprzez zastosowanie osłony gazowej opisywanego obszaru.

\section{Podsumowanie}

Próby spawania laserowego żeber usztywniających z blachą panelu kadłuba nośnego wykazały, że istnieje możliwość uzyskania poprawnych połączeń teowych ze spoiną czołową. Spawanie laserowe bez materiału dodatkowego (spoiwa) może prowadzić do pojawiania się podtopień. Ze względu na konstrukcję panelu kadłuba nośnego jednym z podstawowych wymagań stawianych przez ich producenta jest zminimalizowanie ewentualnych podtopień, w szczególności występujących po stronie blachy panelu, powodujących istotny karb geometryczny w obszarze złącza oraz zmniejszenie nominalnej grubości blachy. Przeprowadzone badania wykazały, że aby zmniejszyć prawdopodobieństwo występowania podtopień należy przeprowadzić proces spawania dwustronnego (spoina czołowa dwustronna w złączu teowym) oraz zastosować odpowiednie parametry procesu spawania.

Duże znaczenie na formowanie się podtopień w procesie spawania laserowego dwustronnych złączy teowych ze spoiną czołową ma położenie miejsca ogniskowania wiązki laserowej - parametr "a". Przesunięcie wiązki laserowej w kierunku żebra usztywniającego - dodatnie wartości parametru „a”, powoduje zmniejszenie intensywności podtopień od strony blachy panelu kadłuba nośnego.

Na jakość złączy spawanych ma wpływ sposób zestawienia i spasowanie elementów do spawania. Stwierdzono, że zastosowanie spawania laserowego punktowego jest wystarczające do trwałego pozycjonowania elementów do spawania. Punktowe spoiny sczepne nie powodowały zakłóceń procesu spawania laserowego.

Niedokładne spasowanie elementów - szczeliny jakie mogą się pojawić pomiędzy blachą panelu kadłuba nośnego a żebrem usztywniającym, mogą spowodować wystąpienie istotnych niezgodności, a w skrajnym przypadku brak połączenia. Newralgicznym odcinkiem złącza, w którym przed spawaniem zmierzono szczelinę pomiędzy łączonymi elementami o wartości powyżej 0,1 mm jest miejsce występowania spoiny konstrukcyjnej panelu kadłuba nośnego. W tym obszarze została zmniejszona przez producenta wysokość żeber usztywniających poprzecznych, w celu zniwelowania trudności ze spasowaniem elementów wynikających z nadlewu spoiny konstrukcyjnej panelu kadłuba nośnego. Powstała w ten sposób szczelina była za duża, co powodowało jedynie nadtopienie przez wiązkę laserową krawędzi i powierzchni łączonych blach bez utworzenia spoiny. Ze względu na to, że spasowanie żebra usztywniającego poprzecznego z blachą panelu kadłuba nośnego w miejscu występowania spoiny konstrukcyjnej panelu może być trudne (każdorazowo należałoby dostosować żebro do danego miejsca spawania), warto rozpatrzyć zmianę konstrukcyjną żebra usztywniającego poprzecznego, polegającą na wydłużeniu ścięcia żebra tak, aby spoina łącząca żebro z blachą panelu kończyła się przed spoiną konstrukcyjną panelu kadłuba nośnego. Spasowanie żebra wzdłużnego z blachą panelu było bardzo dobre, szczelina pomiędzy żebrem wzdłużnym, a blachą panelu wynosiła poniżej $0,05 \mathrm{~mm}$.

Obecnie trwają wstępne próby spawania laserowego żeber usztywniających w zakładzie produkcyjnym.

\section{Literatura}

[1] Pod red. J. Pilarczyka: Poradnik inżyniera Spawalnictwo tom I i II, Wydawnictwa WNT, Warszawa 2014

[2] Brózda J.: Stale konstrukcyjne i ich spawalność. Instytut Spawalnictwa, Gliwice 2009, ISBN 978-83-611272-20-5.

[3] Stano S., Adamiec J., Dworak J., Urbańczyk M.: Badania procesu spawania laserowego złączy teowych z cienkich blach austenitycznych. Biuletyn Instytutu Spawalnictwa, nr 5, 2016, s. 141-151.

[4] Różański M., Stano S., Grajcar A.: Spawanie laserowe i obróbka cieplna stali typu 0H15N7M2J, Biuletyn Instytutu Spawalnictwa, Vol. 60, nr 4, 2016, s. 51-57.

[5] Kubiak M., Piekarska W., Stano S., Saternus Z., Domański T.: Numerical Prediction Of Deformations In Laser Welded Sheets Made Of X5CrNi18-10 Steel. Archives of Metallurgy and Materials. Volume 60, Issue 3, pp. 1965-1972 ISSN (Online) 2300-1909, DOI: 10.1515/amm-2015-0334, November 2015.
[6] Kurc-Lisiecka A., Piwnik J., A. Lisiecki A.: Laser Welding of New Grade of Advanced High Strength Steel STRENX 1100 MC. Archives of Metallurgy and Materials 62, 3, 2017, pp. 1651-1657.

[7] Lisiecki A.: Effect of heat input during disk laser bead-on-plate welding of thermomechanically rolled steel on penetration characteristics and porosity formation in the weld metal. Archives of Metallurgy and Materials 61, 1, 2016, pp. 93-102.

[8] PN-EN ISO 13919-1:2002 - Spawanie - Złącza spawane wiązką elektronów i wiązką promieniowania laserowego - Wytyczne do określenia poziomów jakości według niezgodności spawalniczych - Część 1: Stal. 